Article

\title{
Evidence and Experience of Open Sustainability Innovation Practices in the Food Sector
}

\author{
Gabriella Arcese *, Serena Flammini, Maria Caludia Lucchetti and Olimpia Martucci \\ Department of Business Studies, Roma Tre University, Via Silvio D’Amico, Rome 77-00145, Italy; \\ E-Mails: serena.flammini@uniroma3.it (S.F.); mariaclaudia.lucchetti@uniroma3.it (M.C.L.); \\ olimpia.martucci@uniroma3.it (O.M.)
}

* Author to whom correspondence should be addressed; E-Mail: gabriella.arcese@uniroma3.it; Tel.: +39-06-5733-5713; Fax: +39-06-5733-5797.

Academic Editor: Marc A. Rosen

Received: 26 April 2015 / Accepted: 17 June 2015 / Published: 24 June 2015

\begin{abstract}
The adoption of an "open sustainability innovation” approach in business could be a strategic advantage to reach both industry objectives and sustainability goals. The food sector is facing a constant increase in competition. In order to address the high competition that involves the food industry, sustainability and innovation practices can be strategically effective, especially with an open sustainability innovation approach. In the literature, we found many examples of open innovation applications and their implications for sustainable strategy. These applications are important for reducing cost and time to market, as well as for a company's impact on the environment and food security. In this paper, the authors show the evidence of these implications. In particular, starting from the state of the art of the food sector, we highlight the empirical results of ten case studies. By analyzing these cases, we can gain a better awareness on how and why these approaches are currently being applied by food sector companies.
\end{abstract}

Keywords: sustainability; food sector; open innovation; innovation 


\section{Introduction}

In the food sector, a larger variety of consumers' needs and a shorter lifecycle of products tend to increase competition. An advantage of this competition is its strategic encouragement of sustainability [1].

The increased attention towards social, economic and environmental issues for sustainable development pattern creation offers a more credible and valid image of a company for its customers and business partners [2]. In fact, as reported, the green product innovation has been recognized as a strategic marker for several components, such as profit growth, environmental sustainability and better life quality [3]. The problem, however, is that the food industry "is seen as a low-tech industry with a dominance of incremental rather than radical innovation and a relatively low innovation rate. However, Open Innovation is widely adopted” [1]. OIS's implementation is further supported by the following factors and players:

- the growing number of supply chain actors;

- the variety of customers' demands;

- end-users;

- legislators and higher quality standards requiring the food sector to open up to new sources of innovation in order to continue to be profitable and successful on the market [4].

In the generation of sustainable ideas, services and products exploiting the open innovation paradigm [5], it becomes evident that open innovation practices merge with the sustainability concept. The main objective of this study is therefore to understand how companies are adopting an open sustainability innovation approach, and why it would be strategically beneficial to a food company.

The study begins with an overview of the state of the art of the food sector from a sustainability and Open Innovation perspective. Afterward, we present ten food sector company case studies that, in our view, have adopted and/or are adopting an open sustainability innovation approach in their business practices. Through analyses of these cases, better awareness of how and why this approach has been applied by food sector companies can be gained.

\section{State of the Art}

\subsection{Food Sector}

The food sector is a key sector of the global economy that generates more than four trillion US dollars in annual retail sales [6]. It includes several elements: production, retail, agriculture, and consumer society [7].

The food sector has a strategic importance in the global economy and it encompasses many heterogeneous actors that have to interrelate constantly with the variety of demands from customers, end-users and legislators, but also with shorter lifecycles of products, higher quality standards, food safety and competitiveness.

In Europe, the food sector is extremely important [8] in terms of turnover, value added and employment; it represents one of the main manufacturing sectors. In fact, the food and drink industry has an estimated turnover of $€ 1048$ billion (2012) and a value added of $€ 206$ billion (2011). In 2012, EU companies directly employed 4.24 million people [9]. 
In the food sector, actors build a wide and complex structure (Figure 1); they need to cooperate if they want to meet higher standards of competitiveness, sustainability and social responsibility [10]. Indeed, in order to react to the numerous food scandals and therefore guarantee the product's quality and safety, the food supply chain implemented regulatory systems and made transparency a key practice [11].

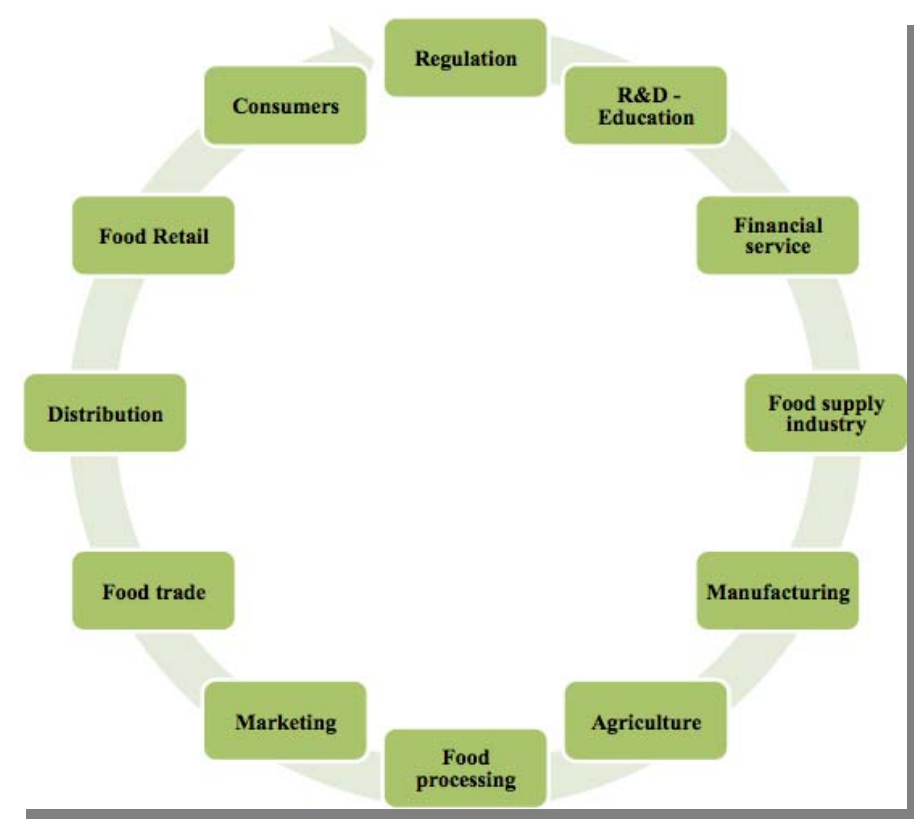

Figure 1. Food sector structure. (Authors' elaboration based on $[7,10]$ ).

From the above figure (Figure 1) it is possible to visualize how the global food industry forms a complex structure that includes a large variety of structures: production farms, small and medium enterprises, and multinationals [12,13]. This sector is characterized by a high level of heterogeneity in the type of enterprises, variety of production, and retail and distribution organization [7,14]: "The food and drink industry maintains the characteristics of a stable, non-cyclical and robust sector against the backdrop of the present economic downturn" [15]. In fact, food and drink production in the European manufacturing industry has been one of the most stable, from 2008 to 2013, right after pharmaceutical production [9].

Compared to the heterogeneous global structure of the food industry, the dimension of Europe's food sector infrastructure is made up of about 286,000 companies, of which the $99.1 \%(283,000)$ are micro or small and medium enterprises (SME) $[9,16]$. Even though the European food market is one of the most important in Europe, and in spite of the high number of food companies, the majority of these are SMEs and only a limited number of them, along with the European multinationals, can compete on the global market [15].

At this point of our analysis, it seems relevant to underline some specific issues in the food sector (Table 1) [10,17]: 
Table 1. Specific issues in the food sector. (Authors' elaboration based on [10]).

\begin{tabular}{|c|c|}
\hline Issue & Explanation \\
\hline $\begin{array}{c}\text { Rapid } \\
\text { adaptation } \\
\text { to different } \\
\text { scenarios }\end{array}$ & $\begin{array}{l}\text { A rapid adaptation to new scenarios is needed [18] in which the process of coordination and communication between } \\
\text { the main actors of the food sector requires the ability to face constantly changing difficulties. Traditionally, the food } \\
\text { industry is considered a low-tech industry that is technology supply-dependent. Innovation in food companies is usually } \\
\text { seen as a balance between the technology-push and the demand-pull approaches. It is hardly ever radical, and more } \\
\text { often has an incremental nature [19]. } \\
\text { As Saguy and Sirotinskaya [20] note, the needs in this kind of industry require that the open innovation process has } \\
\text { radical openness, providing a foundation built on four pillars: collaboration, transparency, sharing and } \\
\text { empowerment. Furthermore, universities develop and dismiss scientific discoveries, knowledge, inventions and } \\
\text { technologies through motivated and highly qualified researchers who contribute to the huge success of the } \\
\text { industry-university partnership [20]. }\end{array}$ \\
\hline $\begin{array}{c}\text { Innovative } \\
\text { problem } \\
\text { solving }\end{array}$ & $\begin{array}{l}\text { It is the need to overcome the structural problem that comes from the numerous SMEs in the European food } \\
\text { sector [12,21]. To do so, companies need to cooperate and look for possible external support. Food industry has } \\
\text { changing processes that simultaneously focus on safety, high quality food and on health and consumer satisfaction [22]. } \\
\text { The chain reversal process that puts the consumer at the center of production implies that companies have to find } \\
\text { new innovative technological solutions and find new business models [22]. Therefore the latest important changes in } \\
\text { the food demand and in the supply chain organization in a more competitive environment have made innovation a } \\
\text { fundamental corporate activity extremely relevant to the profitability of the industry. The actors that cooperate in the } \\
\text { supply chain cooperation mechanism could be a large company or a small firm. Innovative food companies that want } \\
\text { to increase their knowledge may need to associate with other actors of the supply chain as well as with external } \\
\text { possible partners such as: universities and research centers or other industries such as biotechnology, preservation, } \\
\text { technology and nanotechnology [22]. }\end{array}$ \\
\hline $\begin{array}{l}\text { Attention to } \\
\text { consumer } \\
\text { needs }\end{array}$ & $\begin{array}{l}\text { Special attention to consumer needs means that enterprises in this sector are willing to reach the } \\
\text { consumers and take their needs into consideration. In this way enterprises could develop technologies, } \\
\text { management and communication strategies between enterprises and consumers with the aim of building a trusting } \\
\text { relationship [23,24]. } \\
\text { Through collaboration with customers comes the need to satisfy them. Therefore, their involvement is crucial. } \\
\text { Consumer engagement is natural and essential in this type of company; however, consumers have acquired a further } \\
\text { role, more expansive and critical-they have become what is known as "co-creators" [20]. } \\
\text { The companies include in their collaborative networks of community real and virtual consumers. This allows them } \\
\text { the concept of a participatory model of consumers and cooperation on a larger scale, reaching the global market. } \\
\text { Consumers share their experiences of food products, and evaluate their attributes (charm, value, acceptance, ideas, } \\
\text { feelings, emotions and experiences) and provide feedback. } \\
\text { Also, they have a set of tools for creating value, in the role of co-designers, innovators, marketing or branding [25]. } \\
\text { More and more often, consumers demand products closely tailored to their specific needs and health interests, } \\
\text { meaning the industry is constantly and rapidly increasing. Therefore, in order to better meet the new and } \\
\text { differentiated consumer tendencies, companies have developed more complex marketing techniques. These new } \\
\text { challenging tendencies have also compelled the food companies to develop different types of products and to find } \\
\text { more technologically innovative solutions and newer business models [22]. }\end{array}$ \\
\hline
\end{tabular}

For the food sector, innovation and sustainability are considered key strategic factors to overcome the issues of the sector and to achieve worldwide competitiveness goals [26-31], the data have revealed a low research and development ( $\mathrm{R}$ and $\mathrm{D}$ ) intensity that, in Europe, is estimated around $0.27 \%$ [9,30-32]. 
In the literature, several authors state that the food sector is characterized by the predominance of incremental innovations instead of radical ones [27,31,33]. According to Capitanio et al. [30], the predominance of incremental innovation is caused by demand and consumer resilience to change.

The food business sector is currently becoming a more consumer-oriented market that requires constant development in order to keep up with customers' expectations. Other critical aspects that have to be dealt with at the same time are the shortening of products' lifecycles, the heterogeneity of the customers' needs and their requests for a variety and a higher quality of products [34-36]. As many studies have shown, food sector companies that successfully innovate are those which are mostly market, oriented [31,37,38]. From this approach, we can see that, the food sector also benefits from those innovations that come not only from inside the company but also from the outside, as is conceptualized in the paradigm of Open Innovation [39].

In this scenario, in order to face customer demand for higher quality products and more safety, sustainability becomes a key factor in the food sector competitiveness [40]. In fact, it is a strategic marker for a company in terms of image and credibility with customers and, in general, with all the stakeholders [2].

\subsection{Sustainability in the Food Sector}

Over the last couple of decades, the role of sustainability in company business strategies has increased both in terms of brand image and added value. During this time, several measures that analyze enterprise contributions to sustainability have been suggested, such as for example, those that state that companies contribute to sustainability when the value created overtakes the external damage done; another measure is reported by those studies that suggest eco-efficiency, namely, sustainability takes place when companies “create as much value per environmental impact as possible” [41,42].

A third measure, known as the Sustainable Value Added "takes into account both, the efficiency and the absolute level (effectiveness) of resource use. Sustainable Value Added is the extra value created when the overall level of environmental and social impacts is kept constant" [42].

Success in innovation has been evaluated according to the market perspective. This means that the results are considered in terms of economic aspects. More recently, however, the non-economic aspects have become significantly interesting for corporate management and consequently for innovation management [43]. Therefore, the concept of sustainable development has been greatly supported by the awareness of the non-economic aspects in management [44].

The central concept of sustainability has been defined by Brundtland as the "[..] Development that meets the needs of the present without compromising the ability of future generations to meet their own needs" [45]. In the literature the discussion about sustainable development could also take place through the capital theory approach to sustainability [42,46-48]. The capital theory approach comprehends "Man-made capital (such as produced goods), human capital (such as knowledge and skills), natural capital (such as natural resources), and social capital (relationships between individuals and institutions). It follows, according to the constant capital rule, that development can be called sustainable if it ensures constant capital stocks or at least constant capital services over time” [42,49-53].

It is well known that sustainable development can be mirrored by a series of economic, environmental and social factors strictly related to each other [54]. In recent years in the food sector, 
the concept of value creation with consumers has received a great deal of attention in the innovation and sustainability literature [55]. Companies accept that "connected, informed and active" consumers are a source of competence that can be highly useful to add value also to sustainable production (Figure 2) [56].

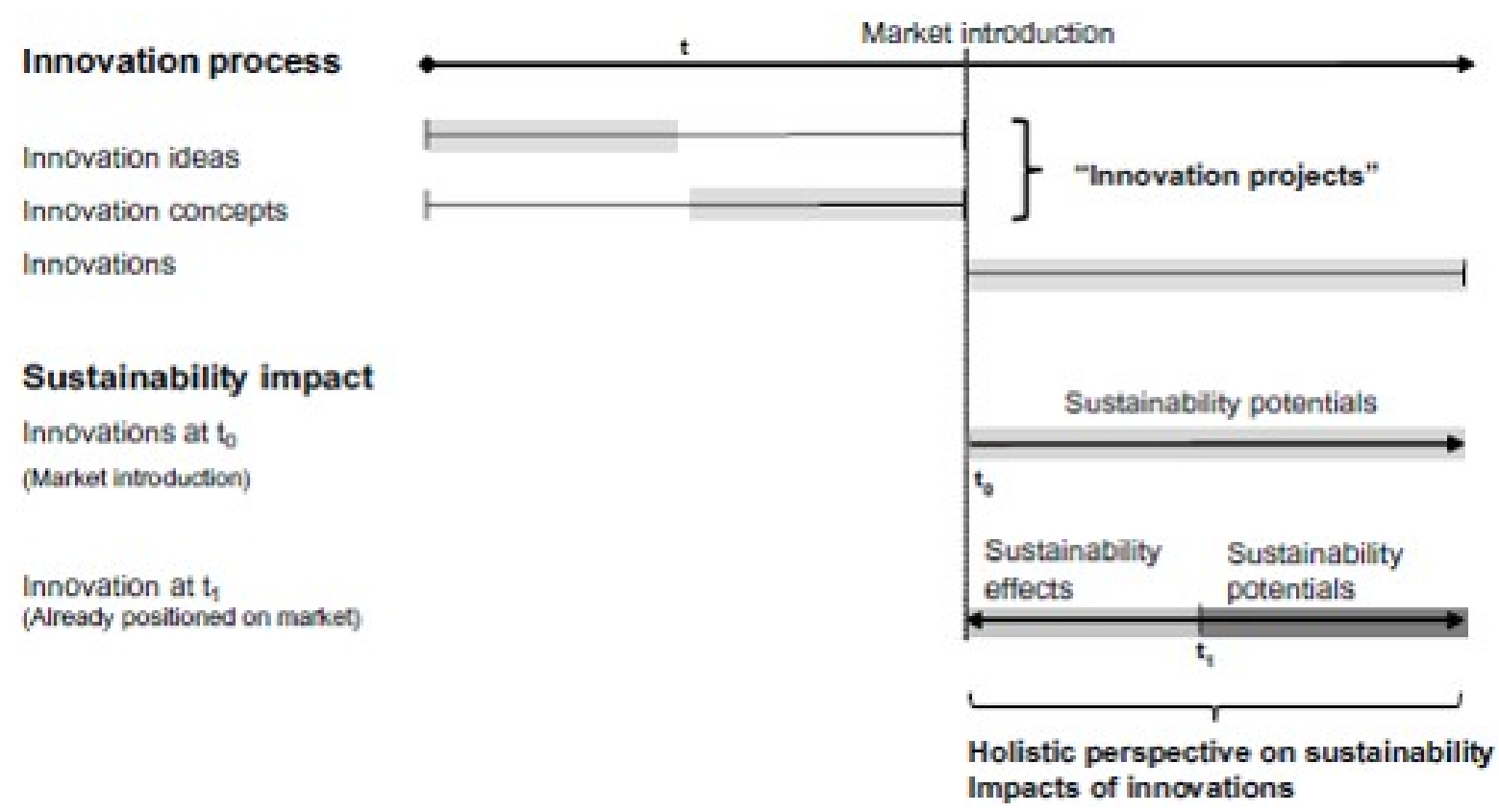

Figure 2. Conceptual basis [56].

The food and drink industry has also had a process of "change reversal" to include the voice of the consumer as a relevant aspect of the innovation process [57]. The value chain thinking is now becoming dominant as a concept that has been able to transform subjective consumer needs (i.e., health, diet, convenience, ethics) into objective and sustainable products, adding value to the product leaning on their sustainability impact [55].

In the food sector, all actors in the chain affect the total sustainability of the chain itself [58]. Indeed, the whole food system has a strong impact on climate change, starting from the agricultural processing to distribution, retail, home food preparation and waste [59]. For example, concerning food wastage, "FAO estimates that each year, approximately one-third of all food produced for human consumption in the world is lost or wasted" [60].

Some of the main issues on sustainability can be synthetized in three macro-areas (Table 2): Socio-economic, production consumption [59].

Table 2. Sustainability issues in the food sector. (Authors' elaboration based on [59]).

\begin{tabular}{cr}
\hline Sustainability Issues & Requirements \\
\hline $\begin{array}{c}\text { Socio-economic } \\
\text { Production }\end{array}$ & The governance of the food sector needs to be constantly updated. \\
Consumption & The food production needs to be implemented by using more sustainable, technological and efficient systems. \\
\hline
\end{tabular}

Socio-economic: From a socio-economic perspective, the latest institutional changes have made social and environmental sustainability key factors in the institutional legitimacy of corporations [2,61]. 
In light of that, in the last decade, the literature on corporate governance has grown so much that also the concept itself has expanded to now include aspects that in the past were considered part of corporate social responsibility (CSR). This is because the concept of sustainability has achieved legitimacy among stakeholders [2,62].

The need to reach a general consensus has influenced companies in their ethical and social engagement so that CSR and Social Accountability Standards, such as SA8000 [63], have become cornerstones of product sustainability [64]. Models of indicators designed to assess social sustainability vary in nature and composition, although some studies show that these are still incomplete and most of them are not objective [2].

Production: At present, production systems face a variety of challenges: supplying food to a worldwide population, supplying energy while reducing $\mathrm{CO}_{2}$ emissions in secure and affordable ways, and taking steps to control the impact of climate change [65]. For example, agriculture and food production generate $29 \%$ of worldwide emissions of greenhouse gases (GHG) [66,67].

Consumption: "Both traditional and modern supply chains offer risks and opportunities for achieving better nutrition and more sustainable food systems. Improvements in traditional supply chains can help reduce losses, lower prices and increase diversity of choice for lower-income households. The growth of modern retailing and food processing can facilitate the use of fortification to combat malnutrition, but the increased availability of highly-processed, packaged goods may contribute to overweight and obesity" [68].

In Europe, food consumption is estimated to influence 30\% of various environmental impacts [67,69].

From the scenario we have sketched so far, we can say that consumers play a leading role in the sustainability of the food chain. The choices that consumers make when they buy food influence both the types of food and the ways in which food can be produced. "While the way food is being produced can be changed by regulation, market forces are a major driver in the way food chains are developing. And here consumers have a crucial role" [58].

As a result of all the factors discussed so far, we can see that technological innovations and managerial changes can be considered crucial to reducing environmental impacts and to increasing resources [59]. It is possible to find several ways for companies to change their outlook with more emphasis on sustainability.

\subsection{Open Innovation in the Food Sector}

The popularity of the Internet increased the competition among companies, while the barriers into the market that had been imposed by larger corporations were subsequently reduced. Therefore, a faster time to market has become one of the main objectives for most companies-this reduction allows enterprises to gain competitive advantages both in terms of competition and turnover [70]. In the face of such strong competition, companies from different sectors have built a double strategy. On the one hand, they started acquiring technologies from the outside environment [71-74], and on the other, they started to externalize their own technology knowledge [75-78].

The advantages of Open Innovation practices deriving from inter-firm cooperation are increasing. Analyzing Open Innovation from a company process perspective, Gassmann and Enkel identified three 
archetypes in the open innovation processes whereby each represents a different strategy: the outside-in process, the inside-out, and the coupled process [79].

According to the Chesbrough paradigm [39] open innovation can be seen at the baseline of the knowledge of a company through external and internal flows of innovation. Therefore, the use of open innovation strategies could become a relevant structure for the growth of SMEs, as well as large firms, as participation in networks gives access to a wide range of knowledge that can lead to a successful innovation process (Figure 3) [80-82].

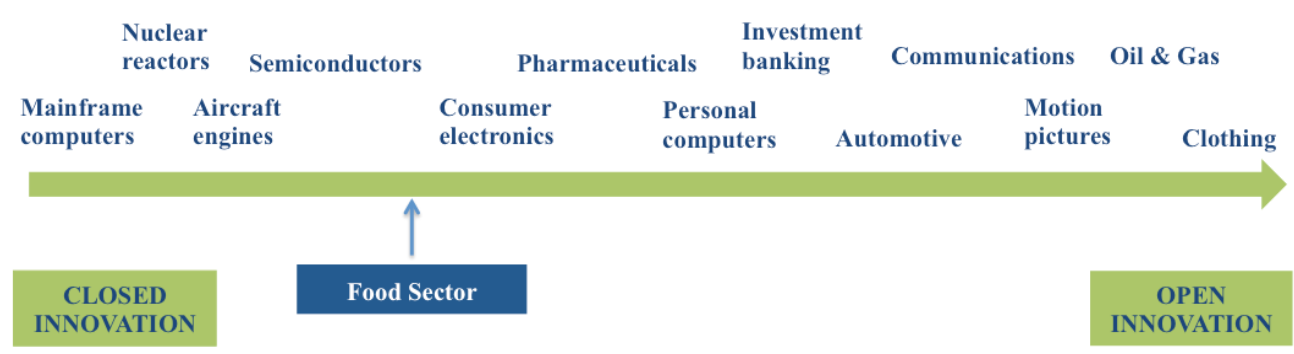

Figure 3. Open innovation in different industries. (Authors' elaboration based on [39,83]).

While over the last ten years the typical sectors associated with open innovation were those characterized by high-technology and quickly developing trends [4], there is less evidence of OIA paradigms in sectors characterized by lower technology intensity [84].

In fact, the food-processing industry has thus far been considered quite conservative with slow growth and a low level of $\mathrm{R}$ and $\mathrm{D}$ investment, and quite reluctant to introduce innovative ideas to the market $[4,85]$. The reluctance to change could be attributed to the perception of its customers that largely seem less willing to accept radical changes in their consumption patterns. Therefore, the perceived customer speed and the constraints of legal requirements needed to guarantee safety have had a strong impact on the innovation process. Until recently, these factors have made it a complex, time-consuming, risky and implausible undertaking [4].

Nowadays, as many studies have pointed out, innovation could become an effective tool also for traditional and mature industries [4]. In support of that, Chesbrough and Crowther [86] found evidence that open innovation strategies are being applied also to companies that operate in lower-tech sectors.

In order to ensure profitability and competitiveness in a global market, firms have begun to consider several factors. The main factors that can lead to open innovation are [38]:

- A different nature of food demand.

- A different organization of food supply.

- A more differentiated demand from consumers in terms of quality, variety and convenience.

- A different demand for healthy food with a low ecological impact.

- A different approach to food safety.

All these factors compel organizations to look for innovative technical ideas, solutions and new business models [87]. Therefore, because the aforementioned innovation requires different approaches, firms have changed their perspective, moving from a supply-based approach to a consumer-based approach [38]. 
Therefore, the combination of the aforementioned factors, along with a further evolution in biotechnology, have given way to a new attitude in the food industry, one that now takes into consideration how all the aforementioned factors are strongly interrelated. These companies are now more aware of the great possibilities offered by the development of technological and scientific knowledge. If these companies are able to include more of this knowledge in their processes, it would be possible for these firms to become increasingly innovative and competitive in the sector.

In the New Food Economy, several studies have indicated that enterprises in the food sector depend on external sources of information for their innovation, and therefore they have to open their network in order to become part of their own innovation processes $[88,89]$.

From the consumer perspective, it is possible to see that in the past they were considered passive targets of a new product. Nowadays, consumers have become a significant element in the value chain. The proliferation of Web and social networks has given consumers the ability to contact companies directly and vice versa; consumer and company roles have become more and more linked, resulting in co-creation. In this way, it is possible to build a win-win process of innovation, for both consumers and companies [90].

"Co-creation offers a new way to innovate, in which prosumers work in mutually beneficial collaboration with companies to develop products, often through social networking," where the term prosumers is derived by combining the words producer or professional and consumer [90]. Co-creation offers food and drink companies the possibility to add value to their products; by understanding what consumers value and by engaging them in interaction and active dialogue, food and drink companies can develop a product that is meaningful to their target consumer base [55,90].

Therefore, there are many tools linked to open innovation applicable to the food industry as, for example: crowdsourcing, crowdfunding, open sourcing, strategic alliances, venturing, and so on [20].

\section{Research Design}

\subsection{Aims and Methodology}

The purpose of this study is to carry out a first explorative investigation to understand how companies are adopting an open sustainability innovation approach, and why it could be strategically meaningful in the business practices of a company operating in the food sector. In order to do so, two main research questions emerged [91].

- How are companies applying an open sustainability innovation approach?

- Why are companies applying an open sustainability innovation approach?

To pursue these aims, the most suitable methodology identified has been the exploratory case study method [92]. Through this methodology, it is possible to answer the "how" and "why" questions [93] set out as the main objectives of this analysis. The methodology based on case study analysis examines situational complexity as a vital part of social and behavioral science research [94]. Yin (2009) specifies that the evidence that can emerge from this research design is not easily generalizable [55,92].

We gathered information through secondary data, integrating the evidence from the literature and case studies. 
First of all, we have identified and analyzed the cases emerging from the existing literature, specifically scholarly articles. Then we looked at public documentation such as: company websites, press articles, corporate presentations, corporate brochures and annual reports. All the online information was collected through the use of keywords, such as: open sustainability innovation, sustainability, food sector, open innovation food sector, and open innovation projects. After that, we screened all the information and selected the cases for analyzing companies from the food sector, identifying them through the open innovation process used to reach sustainable goals. We thus defined the sample by looking at six main variables considered useful to assess the research questions: the existence of at least an open innovation project, the open innovation tool applied, sustainability projects, types of innovation, the technology/technologies that support the project, and the main scope of the projects. In conclusion, we have organized the data in tabular form to facilitate the reading and the comparison among companies.

From the data collected, we finally identified a sample of 10 projects that, in our opinion, can be said to employ an open sustainability innovation approach. Even if it is a small sample for analysis, nevertheless it can provide some interesting insight into the topic and lead to further studies. However, we did take into consideration both large and small firms operating in the food sector for comparison.

\subsection{The Sample}

The research focuses on 10 cases of: Starbucks, Back to the Roots (BTTR), The Plant, Unilever, Nestlé, Coca-Cola, Kraft Foods, Molinos Rio de la Plata, Zero Carbon Food (ZCF); Tate and Lyle.

Starbucks: In 2010 Starbucks decided to sponsor a campaign in order to reduce paper cup wastage. To pursue this objective, the company decided to sponsor an external group of partners that had already started a project addressing the issue of disposable cups, "Betacup Project” [95]. This project consisted in launching an online crowdsourcing public contest on the Jovoto creative platform, providing a summary on the global problem of paper coffee cups and a monetary prize of $€ 10,000$ plus $€ 2,000$, 1st-5th place [96]. The task was: "Rethink the way we consume coffee and present solutions that strive to reduce paper cup waste [96].” After two months, the Betacup contest received 430 idea submissions, 1,500 idea revisions, more than 5000 comments, 13,000 ratings and a winner [95]. The winner was a low-tech solution known as "Karma Cup" a "chalkboard sitting by [each Starbucks] register. Every guest who uses a reusable mug marks the chalkboard. Every 10th guest receives a free item" [97].

"The creative collaboration contest not only produced a huge number of innovative ideas for Starbucks and provided it with insight about its product strategy, it raised awareness of an important issue that Starbucks was addressing and thus earned Starbucks valuable media” [95] Along with these considerations, the Betacup Project, thanks to the co-creation model, allowed the discovery of a suitable solution, already positively prototyped, in a relatively short time and with less investments in $\mathrm{R}$ and D. This case study is an example of the effectiveness that open sustainability innovation can have from a marketing perspective.

Back to the Roots (BTTR): It is a small California-based company established in 2009. Their mission is: "to make food personal again through the passionate development of tools that educate and inspire, one family at a time” [98]. While the founders of BTTR were searching for product 
diversification and development, they noticed a business opportunity in the designing of a home aquaponic system: "Aquaponics is a centuries-old, closed-loop method of growing food that utilizes fish waste to fertilize the plants, which then clean and oxygenate the water for the fish.” [99] In order to fund the production of the home aquaponics kit in November 2012, BTTR which at that time was still a startup company, launched a crowdfunding campaign on Kickstarter, a crowdfunding online platform [100,101]. Through this campaign, BTTR raised \$248,873, blowing away their initial goal of $\$ 100,000$. The campaign was a success for them not only in terms of getting the necessary funding, but also for receiving feedback from potential customers, thereby allowing them to customize the product to better fit customer needs and to validate the market demands for a home aquaponics kit [99]. This crowdfunding campaign is a successful example of co-creation illustrating how much customers care about sustainable products and how strong the co-creation approach is in terms of lower time to market, costs and product validation.

The Plant: As described on their website, the Plant "is a new kind of organization in a very old building. It's part vertical farm, part food-business incubator, part research and education space” [102]. The Plant is a complex structured project rooted upon the concept of sustainability. Concerning the food-business incubator, "The Plant is a center for start-ups for existing food producing businesses to develop into viable, sustainable ventures. The Plant's business incubator consists of permanent tenant spaces maintained by Bubbly Dynamics, LLC, and will offer food-producing businesses the advantage of reduced rent and energy costs. All food waste generated by these businesses will be processed in an onsite anaerobic digester to create biogas for The Plant's renewable energy system. This self-sustaining, interconnected process helps the businesses housed in The Plant grow and prosper together, while creating new, green jobs in the community.” [103]. As it is described, the business incubator has multiple functions for transforming food businesses into sustainable companies, to reduce the costs, to create green jobs and at the same time reduce the environmental impact creating renewable energy from food startups' waste. Therefore, the Plant represents another example of a successful open sustainability approach.

Unilever: The well-known multinational company launched on its website in 2012 the Open Innovation Platform through which it aims to find partners to make the world a better place [104,105]. Through its OI platform, Unilever has been launching many projects; especially oriented to reach sustainability goals for: cleaning agents; natural red coloring; sugar/salt reduction; drinking water; antiviral ingredients; packaging; oral care; shower products; natural food preservatives; renewable energy storage systems; devices, technologies or products that change consumer behavior [20]. For example, Unilever aims to reduce the amount of sodium in food products by a further $15 \%-20 \%$ while keeping its products tasty. To pursue this objective, Unilever is using its open innovation platform to look at new ideas to reduce the concentration of sodium in its products or to find alternatives to conventional salt [105]. By pursuing this objective Unilever improves also the social aspects of sustainability by taking care of customers' health.

Nestlé: Nestlé launched the "Ecolaboration” in 2009 [106]. Through Ecolaboration, Nespresso consolidated its sustainability efforts in coffee sourcing, capsule recycling and energy-efficient machines into one concerted program.

Nespresso has an established track record of sustainability, establishing the Nespresso AAA Sustainable Quality ${ }^{\mathrm{TM}}$ Program in 2003 with Rainforest Alliance, through which only the 
highest-quality beans are sourced and where farmers are paid a premium. In 2009, almost 50\% of the total green coffee beans Nespresso purchased came from its AAA Sustainable Quality ${ }^{\mathrm{TM}}$ Program, and Nespresso has committed to increase this to $80 \%$ by 2013 [106]. Ecolaboration builds on all such activities, taking them a step further and extending the approach across the value chain for a broader and deeper level of sustainable success. Through this new framework, Nespresso will formalize its relationships with technical experts, NGOs, business partners and other key stakeholders, sharing best practices and collaborating on new ideas and innovations to improve the sustainability performance of Nespresso [106]. Therefore, it will use strategic alliances as an open innovation tool in order to improve its sustainable objectives.

Coca-cola: Coca-Cola in the "recycle for the future" program has worked closely with the University of Exeter to understand consumer recycling behaviors at home, and has launched a recycling challenge in partnership with the open innovation platform OpenIDEO.com (Coca-Cola, 2013). The recycling challenge was launched in 2014 in the UK and France to co-create solutions to help improve at-home recycling habits in those countries. It is an 11-week challenge drawn on the platform's 60,000 members from across the 130 partner countries as part of CCE's Recycle for the Future campaign [107].

Kraft: Kraft Foods conducts many activities, projects and partnerships to promote innovation and sustainability. An example of its activities is the strategic alliance with TerraCycle in order "to collect used Capri Sun drink pouches for upcycling and to manage packaging waste” [108]. According to Thota (2012) Kraft's partnership with TerraCycle has changed over time, evolving from a transactional "waste-centric" perspective to a "growth-centric" alliance. A more recent open innovation project powered by NineSights is the project known as "Collaborative Kitchen," through which they "recognize that this innovation can come from many sources and that there are great ideas out there in other business sectors, at the other end of the size chart to individual inventors and all the way in between. We're looking for new partnerships to develop these ideas, to enhance and speed up our innovation and to create partnerships where all involved succeed” [109]. In this case the OI tools adopted by Kraft could be referred to co-creation and strategic alliances.

Molinos Rio de la Plata: As one of the leading companies in the South American food industry, it aims to pursue its mission of a high standard of product quality and process efficiency. Moreover, Molinos works hard to meet the top international standards of environmental protection and food security [110]. In order to pursue these objectives, Molinos has developed an open innovation plan [20] to collect innovative ideas. Therefore the open innovation tool adopted by Molinos could be linked to crowdsourcing. One of the main projects of the companies open innovation plan is linked to the improvement of their product; indeed, they aim to "to improve the organoleptic properties and the nutritional value of our products by making them healthier and more appealing to the consumer” [110]. This consideration can be linked to an interest of the company in the improvement of the social aspects of sustainability by improving customers' health.

Zero Carbon Food (ZFC): ZFC is a London-based startup that cultivates food underground [111]. ZFC began by growing food in an abandoned World War II bomb shelter, running $33 \mathrm{~m}$ under the ground. For two years, ZFC through its "Growing Underground SW4" benefitted many Londoners with reduced food waste, a reduction in the carbon footprint of the city, and water savings [112]. According to Rayapura (2014), in order to achieve its mission, ZCF launched an equity crowdfunding 
campaign on CrowdCube that raised about $\$ 500,000$. Therefore the main OI tool adopted by ZCF seems to be crowdfunding [112].

Tate and Lyle: A UK-based company operating in the food sector, Tate and Lyle specializes in food ingredients [113], particularly: texturants; sweeteners; and health and wellness ingredients [20]. Tate and Lyle has an open innovation platform through which it looks for strategic alliances. The company looks for valuable partners in many areas, such as in health and wellness, for potential projects in, for instance: Dietary fiber ingredients with high digestive tolerance, ingredients that can replace or at least reduce salt in food, food ingredients that are able to reduce blood glucose response to food intake, and many others [113]. These aspects contribute to implement the social aspects of sustainability by upholding the customers' health.

\section{Findings}

As we can see in Figure 4, resources, capabilities and activities enable the creation of persistent competitive advantages that are difficult to imitate and substitute by current or potential competitors.

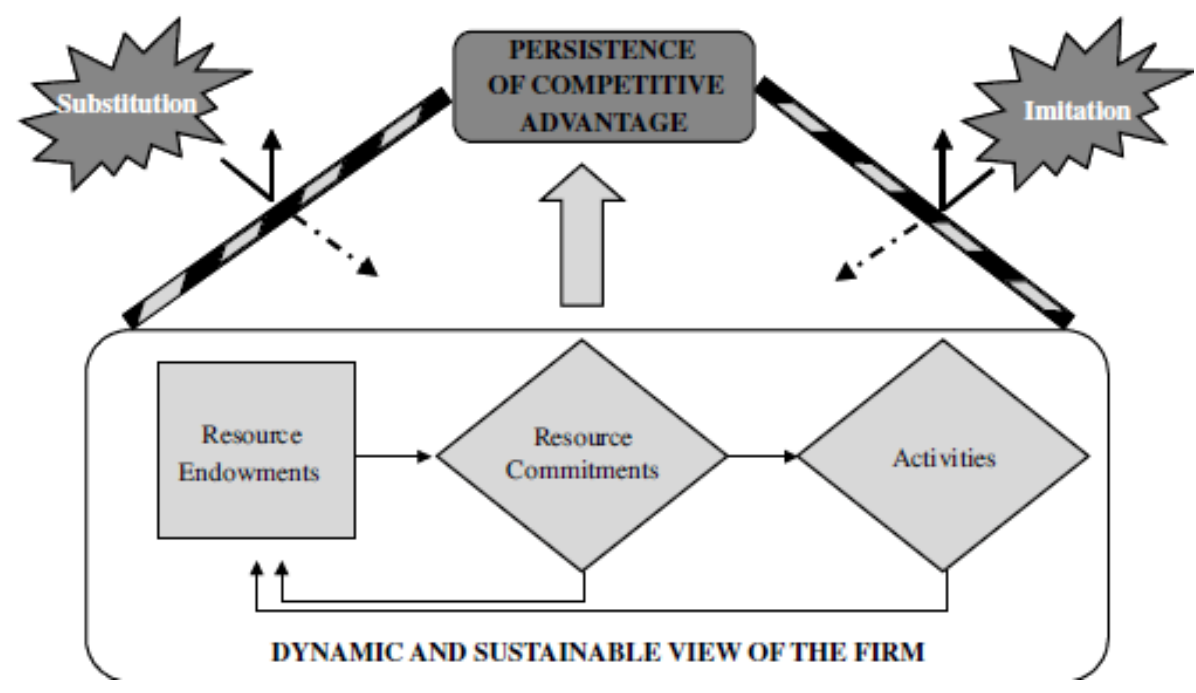

Figure 4. The dynamic firm's point of view [96].

An open sustainability innovation approach could be strategically meaningful for a company that operates in the food sector in order to achieve sustainability and business goals such as: lower cost and time to market, more sustainable environmental impact, an increase in food security, and also a higher attention to social aspects of sustainability. This could be possible in light of the open innovation paradigm and sustainability themselves. In fact, on one hand, according to Chesbrough: "Open innovation offers the prospect of lower costs for innovation, faster times to market, and the chance to share risks with others" [114]. On the other hand, we already observed that customer behavior plays a key strategic role in sustainability, because with their consumption and purchasing habits, they are able to influence the market [58]. Therefore, companies are increasing their willingness both in the co-operation with customers and in the adoption of a sustainability approach. These are the reasons why open sustainability innovation could represent an effective approach to gaining competitive advantages and differentiation [5]. 
"The hope is that companies big and small can benefit from the cost savings and environmental benefits that come from sharing sustainability orientated innovations” [5].

\section{Empirical Evidence}

There are many cases of open innovation related to sustainability, as we will see in the following section. We have defined the concept of open sustainability innovation as an approach by which open innovation practices merge with the sustainability concept. Indeed, to better understand the possible ways by which companies are adopting this approach and the possible implications that could be generated from it, we have collected some evidence on the adoption of an open sustainability innovation approach (Table 3).

Each company is unique, has its own structure, strategy, business model, needs, challenges and opportunities; therefore, it also has its own open innovation needs and manner of dealing with them. Food companies adopt different strategies to assess their open sustainability innovation needs. Some of them are more oriented toward the co-creation process by launching crowdsourcing campaigns, such as Starbucks [5] and Coca-Cola, and in a different way, Molinos Rio del la Plata; others have used crowdfunding to start the project production like Back to the Roots (BTTR) [98], Zero Carbon Food (2015) [111], or an Omni-comprehensive open sustainability innovative organization project like The Plant [102]. Other projects stimulate co-creation by looking and building strategic partnerships, as is the case in many large companies, including Kraft, Unilever, Tate and Lyle, and Nestlé. These cases are just some examples of how companies adopt an open sustainability innovation approach in the food sector.

From the aforementioned case studies, we can see that some companies have embraced a consumer-driven approach to innovation with a consumer-centric culture, and by experimenting with consumer-led co-creation. In fact, what emerges from the selected cases is that, regardless of the open innovation tools adopted in order to reach sustainability goals, co-creation, as a strategic lever to implement innovation, technologies and answer to customers’ needs, has been involved.

There are still companies that prefer to remain with more traditional consumer-based methods. In general, the food sector is traditionally slow in taking up new approaches [90]. Therefore, a paradigm shift is suggested in order to meet the new challenges. In order for a company to be on the path to success, consumers need to become a standard part of the food sector innovation process [90].

It is also important to consider that "The size of the European common market holds many opportunities for companies wishing to increase their productivity, by making effective use of economies of scale. The EU's food industry must also look to stimulate innovation and develop new products in order to thrive. All this must be done in a way that is respectful for the environment and that guarantees secure access to agricultural raw materials” [115]. 
Table 3. Evidence from open sustainability innovation in the food sector. (Authors' elaboration based on [95,97-102,105-108,110,112,113].

\begin{tabular}{|c|c|c|c|c|c|c|}
\hline Company & OI Project & OI Tools & Sustainability's Projects & Innovation Types & Supporting Technology & Scopes \\
\hline Starbucks & $\begin{array}{l}\text { Betacup } \\
\text { Project }\end{array}$ & Crowdsourcing & Reduce paper cup waste & Incremental & $\begin{array}{c}\text { Karma Cup, } \\
\text { a low-tech chalkboard } \\
\text { solution } \\
\end{array}$ & $\begin{array}{c}\text { Lower time to market-Reduce } \\
\text { use of paper cups }\end{array}$ \\
\hline BTTR & AquaFarm & Crowdfunding & $\begin{array}{l}\text { Growing home food from } \\
\text { waste }\end{array}$ & Incremental & Home Aquaponics Kits & $\begin{array}{c}\text { Grow at home food-Reduce } \\
\text { waste Fund the } \\
\text { production-Lower time to } \\
\text { market_-Green Jobs }\end{array}$ \\
\hline $\begin{array}{l}\text { Bubbly } \\
\text { Dynamics } \\
\text { LLC }\end{array}$ & The Plant & Food startups incubator & $\begin{array}{l}\text { “All food waste generated by } \\
\text { these businesses will be } \\
\text { processed in an onsite } \\
\text { anaerobic digester to create } \\
\text { biogas for The Plant’s } \\
\text { renewable energy system”[90] }\end{array}$ & Incremental & $\begin{array}{c}\text { Sustainable-Food } \\
\text { Startup-Businesses- } \\
\text { Incubator }\end{array}$ & $\begin{array}{l}\text { Food waste processed into } \\
\text { The Plant renewable energy } \\
\text { system_Lower operating } \\
\text { costs_-Startups become } \\
\text { sustainable ventures }\end{array}$ \\
\hline Unilever & $\begin{array}{c}\text { Open } \\
\text { Innovation } \\
\text { Platform }\end{array}$ & $\begin{array}{l}\text { Strategic Alliances- } \\
\text { Crowdsourcing }\end{array}$ & $\begin{array}{c}\text { Innovations can help to } \\
\text { provide alternative solution to } \\
\text { conventional salt }\end{array}$ & Incremental & $\begin{array}{l}\text { Open innovation web } \\
\text { platform }\end{array}$ & $\begin{array}{l}\text { Reduction of salt level_-higher } \\
\text { attention to social aspects of } \\
\text { sustainability_-Find new } \\
\text { technologies and } \\
\text { innovations-Better } \\
\text { understand customer needs }\end{array}$ \\
\hline $\begin{array}{c}\text { Nestlé } \\
\text { (Nespresso) }\end{array}$ & Ecolaboration & Strategic Alliances & $\begin{array}{c}\text { Ecolaboration aims to } \\
\text { improve the Nespresso’s } \\
\text { sustainability performances } \\
\text { through collaboration }\end{array}$ & Incremental & Network & $\begin{array}{l}\text { Higher suitability } \\
\text { performances_-Farmers } \\
\text { are paid_-Green use of } \\
\text { 80\% of the coffee beans }\end{array}$ \\
\hline Coca-Cola & $\begin{array}{l}\text { CCE's } \\
\text { Recycle for } \\
\text { the Future }\end{array}$ & $\begin{array}{l}\text { Collaboration with } \\
\text { University of Exeter- } \\
\text { Strategic alliance with } \\
\text { OpenIDEO.com- } \\
\text { Crowdsourcing } \\
\end{array}$ & $\begin{array}{l}\text { Understand home recycling } \\
\text { customer behaviors-Help } \\
\text { improve at-home recycling } \\
\text { habits }\end{array}$ & Incremental & $\begin{array}{l}\text { Research and 11-week } \\
\text { challenge }\end{array}$ & $\begin{array}{l}\text { "Help improve recycling } \\
\text { rates at-home" }\end{array}$ \\
\hline
\end{tabular}


Table 3. Cont.

\begin{tabular}{|c|c|c|c|c|c|c|}
\hline Company & OI Project & OI Tools & Sustainability’s Projects & $\begin{array}{c}\text { Innovation } \\
\text { Types } \\
\end{array}$ & $\begin{array}{l}\text { Supporting } \\
\text { Technology }\end{array}$ & Scopes \\
\hline Kraft & & $\begin{array}{l}\text { Strategic Alliance with } \\
\text { TerraCycle }\end{array}$ & $\begin{array}{c}\text { collect used Capri Sun drinks } \\
\text { pouches for upcycling and managing } \\
\text { packaging waste }\end{array}$ & Incremental & Network & $\begin{array}{c}\text { Upcycling and managing } \\
\text { packaging waste--Speed up } \\
\text { innovation and company growth }\end{array}$ \\
\hline $\begin{array}{l}\text { Molinos Rio } \\
\text { de la Plata }\end{array}$ & $\begin{array}{c}\text { Open } \\
\text { Innovation } \\
\text { Plan } \\
\end{array}$ & Crowdsourcing & $\begin{array}{l}\text { "improve the organoleptic properties } \\
\text { and the nutritional value of our } \\
\text { products by making them healthier" }\end{array}$ & Incremental & $\begin{array}{l}\text { Open innovation web } \\
\text { platform }\end{array}$ & $\begin{array}{l}\text { Healthier food products for better } \\
\text { social sustainability }\end{array}$ \\
\hline $\begin{array}{l}\text { Zero Carbon } \\
\text { Food }\end{array}$ & $\begin{array}{c}\text { Growing } \\
\text { Underground } \\
\text { SW4 }\end{array}$ & Equity Crowdfunding & $\begin{array}{l}\text { Growing food, revaluing abandoned } \\
\text { locations underground }\end{array}$ & Incremental & $\begin{array}{l}\text { "Low-energy LED } \\
\text { lights and an integrated } \\
\text { hydroponics system" }\end{array}$ & $\begin{array}{l}\text { Food waste reduction-Contribute } \\
\text { to reducing the cities carbon } \\
\text { footprint-Water savings-Lower } \\
\text { time to market }\end{array}$ \\
\hline $\begin{array}{l}\text { Tate and } \\
\text { Lyle }\end{array}$ & $\begin{array}{c}\text { Open } \\
\text { Innovation } \\
\text { Platform }\end{array}$ & Strategic Alliances & $\begin{array}{l}\text { Health and wellness food products } \\
\text { for: high dietary fiber ingredients with } \\
\text { high digestive tolerance, ingredients } \\
\text { that can replace or at least reduce salt } \\
\text { in food, food ingredients that are able } \\
\text { to reduce blood glucose response to } \\
\text { food intake }\end{array}$ & Incremental & $\begin{array}{l}\text { Open innovation } \\
\text { web platform }\end{array}$ & $\begin{array}{l}\text { Healthier food products for better } \\
\text { social sustainability }\end{array}$ \\
\hline
\end{tabular}




\section{Conclusions and Possible Future Developments}

The conclusion that can be drawn from our critical examination of the open sustainability innovation in the food sector and from the case studies are manifold.

Although the food sector has been considered a traditional and mature industry, the application of the open sustainability innovation approach has proved that it could be an incremental resource for the sector. Therefore, more research can be suggested in order to gain a better understanding of "how" the use of the open sustainability innovation approach could eventually have a positive influence on the food sector.

For the food sector, the merging of open innovation and sustainability represents an important challenge. This is because from the merging of these two elements, it could be possible to reach goals such as a reduction of environmental impacts, healthier and safer food for an increasing population. At the same time, by leveraging on open innovation strategies, there is also a reduction of some company costs and time to market.

It is becoming clearer and clearer, however, that the food sector has a long road ahead if it is to meet future global challenges successfully [116].

The analyses show that an OIS approach in terms of co-creation and as a tool for implementation and improvement of the sustainability practices, contributes to finding innovative solutions to improve consumer satisfaction.

In the future, the analyses could extend to include a larger number of cases and explore the application of OSI to other companies.

Finally, it should be noted that this is still a preliminary study. The intention of the authors was to test and deepen our understanding of OSI through secondary data. Further discussion and studies, adopting also other support tools (such as direct interviews in the individual companies) will help to see if it is possible to confirm what in the analysis of the case studies took place.

\section{Acknowledgments}

The authors would like to thank the reviewers' suggestions, Elisa Pelatelli, and Ilaria Massa for their contributions to the research project.

\section{Author Contributions}

The authors contributed equally to this work and to its research design. Gabriella Arcese and Serena Flammini analyzed the source and literature and conducted the case studies analyses. Maria Claudia Lucchetti coordinated the study and Olimpia Martucci supervised the research project and carried out a detailed revision. All authors read and approved the final manuscript.

\section{Conflicts of Interest}

The authors declare no conflict of interest. 


\section{References}

1. Martinez, M.G. (Ed.) Open Innovation in the Food and Beverage Industry; Elsevier: Cambridge, UK, 2013; pp. XXXIII-XXXIV.

2. Arcese, G.; Lucchetti, M.C.; Merli, R. Social life cycle assessment as a management tool: Methodology for application in tourism. Sustainability 2013, 5, 3275-3287.

3. Dangelico, R.M.; Pujari, D. Mainstreaming green product innovation: Why and how companies integrate environmental sustainability. J. Bus. Eth. 2010, 95, 471-486.

4. Sarkar, S.; Costa, A.I. Dynamics of open innovation in the food industry. Trends Food Sci. Technol. 2008, 19, 574-580.

5. Belz, F.M.; Peattie, K. Sustainability Marketing: A Global Perspective; Wiley: Hoboken, NJ, USA, 2009.

6. Report Linker. Global Food Industry. Food Industry Market Research \& Statistics, 2014. Available online: http://www.reportlinker.com/ci02024/Food.html (accessed on 23 September 2014).

7. Lehmann, R.J.; Reiche, R.; Schiefer, G. Future internet and the agri-food sector: State-of-the-art in literature and research. Comput. Electron. Agric. 2012, 89, 158-174.

8. CIAA (Central Intercollegiate Athletic Association). Annual Report 2009; Confederation of the Food and Drink Industries in Europe (CIAA): Brussels, Belgium, 2009.

9. FoodDrinkEurope. 2013-2014 Data \& Trends of the European Food and Drink Industry. 2014. Available online: http://www.fooddrinkeurope.eu/uploads/publications_documents/Data_ Trends_of_the_European_Food_and_Drink_Industry_2013-2014.pdf (accessed on 25 September 2014).

10. Fritz, M.; Schiefer, G. Food chain management for sustainable food system development: A European research agenda. Agribusiness 2008, 24, 440-452.

11. Beulens, A.J.M.; Broens, D.-F.; Folstar, P.; Hofstede, G.J. Food safety and transparency in food chains and networks-Relationships and challenges. Food Control 2005, 16, 481-486.

12. O’Reilly, S.; Haines, M.; Arfini, F. Food SME networks: Process and governance-The case of Parma ham. J. Chain Netw. Sci. 2003, 3, 21-32.

13. CIAA (Central Intercollegiate Athletic Association). Report on Data and Trends of the EU Food and Drink Industry; Confederation of the Food and Drink Industries in Europe (CIAA): Brussels, Belgium, 2005.

14. Dagevos, H.; Bunte, F. Expanding the size of the envelope that contains agriculture. In The Food Economy-Global Issues and Challenges; Wageningen Academic Publishers: Wageningen, The Netherlands, 2009; pp. 15-20.

15. FoodDrinkEurope. Data \& Trends of the European Food and Drink Industry 2012. Available online: http://www.fooddrinkeurope.eu/uploads/publications_documents/Data_ Trends_(interactive).pdf (accessed on 30 September 2014).

16. Kühne, B.; Vanhonacker, F.; Gellynck, X.; Verbeke, W. Innovation in traditional food products in Europe: Do sector innovation activities match consumers' acceptance? Food Qual. Prefer. 2010, 21, 629-638.

17. CIAA (Central Intercollegiate Athletic Association). European Technology Platform on Food for Life: Strategic Research Agenda 2007-2020; Confederation of the Food and Drink Industries in Europe (CIAA): Brussels, Belgium, 2007. 
18. Rabbinge, R.; Linnemann, A. European Food Systems in a Changing World; European Science Foundation: Strasbourg, France, 2009.

19. Bigliardi, B.; Galati, F.; Marolla, G.; Verbano, C. Factors affecting technology transfer offices' performance in the Italian food context. Technol. Anal. Strateg. Manag. 2015, 27, 361-384.

20. Saguy, I.S.; Sirotinskaya, V. Challenges in exploiting open innovation's full potential in the food industry with a focus on small and medium enterprises (SMEs). Trends Food Sci. Technol. 2014, 38, 136-148.

21. McCorriston, S. Why should imperfect competition matter to agricultural economists? Eur. Rev. Agric. Econ. 2002, 29, 349-371.

22. Bigliardi, B.; Galati, F. Models of adoption of open innovation within the food industry. Trends Food Sci. Technol. 2013, 30, 16-26.

23. Fritz, M.; Rickert, U.; Schiefer, G. Trust and risk in business networks. In Proceedings of the 99th European Seminar of the European Association of Agricultural Economists, Bonn, Germany, 8-10 February 2006.

24. Kjaernes, U.; Harvey, M.; Warde, A. Trust in Food: A Comparative and Institutional Analysis; Palgrave Macmillan: Hampshire, UK, 2007.

25. Romero, D.; Molina, A. Collaborative networked organizations and customer communities: value co-creation and co-innovation in the networking era. Prod. Plan. Control 2011, 22, 447-472.

26. Rama, R. Empirical study on sources of innovation in international food and beverage industry. Agribusiness 1996, 12, 123-134.

27. Grunert, K.; Harmser, H.; Meulenberg, M.; Kuiper, E.; Ottowitz, T.; Declerck, F.; Traill, B.; Göransson, G. A framework for analysing innovation in the food sector. In Product and Process Innovation in the Food Industry; Traill, B., Grunert, K.G., Eds.; Blackie Academic and Professional: London, UK, 1997; pp. 1-37.

28. Traill, W.B.; Meulenberg, M. Innovation in the food industry. Agribusiness 2002, 18, 1-21.

29. Rama, R. (Ed.) Handbook of Innovation in the Food and Drink Industry; Haworth Press: New York, NY, USA, 2008.

30. Capitanio, F.; Coppola, A.; Pascucci, S. Indications for drivers of innovation in the food sector. Br. Food J. 2009, 111, 820-838.

31. Bayona-Sáez, C.; García-Marco, T.; Sanchez-García, M. The impact of open innovation on innovation performance: The case of Spanish agri-food firms. In Open Innovation in the Food and Beverage Industry; Martinez, M.G., Ed.; Elsevier: Cambridge, UK, 2013; pp. 74-94.

32. Martinez, M.G.; Burns, J. Sources of technological development in the Spanish food and drink industry. A “supplier dominated” industry? Agribusiness 1999, 15, 431-448.

33. Galizzi, G.; Venturini, L. Product innovation in the food industry: Nature, characteristics and determinants. In Economics of Innovation: The Case of the Food Industry; Galizzi, G., Venturini, L., Eds.; Physica-Verlag: Heidelberg, Germany, 1996; pp. 133-156.

34. Trijp, H.C.M.V.; Steenkamp, J.E.M. Consumer-oriented new product development: Principles and practice. In Innovation of Food Production Systems: Product Quality and Consumer Acceptance; Jongen, W.M.F., Meulenberg, M.T.G., Eds.; Purdue University Press: West Lafayette, IN, USA, 1998; pp. 37-66. 
35. Dekker, M.; Linnemann, A.R. Product development in the food industry. In Innovation of Food Production Systems: Product Quality and Consumer Acceptance; Jongen, W.M.F., Meulenberg, M.T.G., Eds.; Purdue University Press: West Lafayette, IN, USA, 1998; pp. 67-86.

36. Costa, A.I.A.; Dekker, M.; Jongen, W.M.F. Quality function deployment in the food industry: A review. Trends Food Sci. Technol. 2000, 11, 306-314.

37. Batterink, M.H.; Wubben, B.F.M.; Omta, S.W.F. Factors related with innovate output in the Dutch agrifood industry. J. Chain Netw. Sci. 2006, 6, 31-44.

38. Fortuin, F.T.J.M.; Omta, S.W.F. Innovations drivers and barriers in food processing. Br. Food J. 2009, 111, 839-851.

39. Chesbrough, H.W. Open Innovation: The New Imperative for Creating and Profiting from Technology; Harvard Business Press: Boston, MA, USA, 2003.

40. Reisch, A.L.; Gerd, S. Sustainable Food Systems. Available online: http://www.scpknowledge.eu/sites/default/files/knowledge/attachments/KU_Sustainable_Food_Systems.pdf (accessed on 1 October 2014).

41. Veleva, V.; Ellenbecker, M. A proposal for measuring business sustainability. Gr. Manag. Int. 2000, 31, 101-120.

42. Figge, F.; Hahn, T. Sustainable value added-Measuring corporate contributions to sustainability beyond eco-efficiency. Ecol. Econ. 2004, 48, 173-187.

43. Christiansen, A.C.; Buen, J. Managing environmental innovation in the energy sector: The case of photovoltaic and wave power development in Norway. Int. J. Innov. Manag. 2001, 6, doi:10.1142/S1363919602000586.

44. Fitzgerald, B. The transformation of open source software. MIS Q. 2006, 30, 587-598.

45. World Commission on Environment and Development. Our Common Future; Oxford University Press: Oxford, UK, 1987; Volume 383.

46. Harte, M.J. Ecology, sustainability, and environment as capital. Ecol. Econ. 1995, 15, 157-164.

47. Prugh, T.; Costanza, R.; Cumberland, J.H.; Daly, H.E.; Goodland, R.; Norgaard, R.B. Natural Capital and Human Economic Survival, 2nd ed.; Lewis Publishers: Boca Raton, FL, USA, 1999.

48. Stern, D. The capital theory approach to sustainability: A critical appraisal. J. Econ. Issues 1997, 31, 145-173.

49. Costanza, R.; Daly, H. Natural capital and sustainable development. Conserv. Biol. 1992, 6, 37-64.

50. Hartwick, J. Intergenerational equity and the investing of rents from exhaustible resources. Am. Econ. Rev. 1977, 67, 972-974.

51. Solow, R. On the intertemporal allocation of natural resources. Scand. J. Econ. 1986, 88, 141-149.

52. Pearce, D. Economics, equity and sustainable development. Futures 1988, 20, 598-605.

53. Pearce, D.; Atkinson, G. The concept of sustainable development: An evaluation of its usefulness ten years after Brundtland. Swiss J. Econ. Stat. 1998, 134, 251-269.

54. Callens, I.; Tyteca, D. Towards indicators of sustainable development for firms: A productive efficiency perspective. Ecol. Econ. 1999, 28, 41-53.

55. Martinez, M.G. Co-creation of value by open innovation: Unlocking new sources of competitive advantage. Agribusiness 2014, 30, 132-147. 
56. Prahalad, C.K.; Ramaswamy, V. The Future of Competition: Co-Creating Value with Customers; Harvard Business School Press: Boston, MA, USA, 2004.

57. Aguilera, J.M. Seligman lecture 2005 food product engineering: Building the right structures. J. Sci. Food Agric. 2006, 86, 1147-1155.

58. Grunert, K.G. Sustainability in the food sector: A consumer behavior perspective. Int. J. Food Syst. Dyn. 2011, 2, 207-218.

59. Garnett, T. Food sustainability: Problems, perspectives and solutions. Proc. Nutr. Soc. 2013, 72, 29-39.

60. Food and Agriculture Organisation (FAO). Food Wastage Footprint Impacts on Natural Resources; Technical Report; FAO: Rome, Italy, 2013.

61. Lee, M.A. Review of the theories of corporate social responsibility: Its evolutionary path and the road ahead. Int. J. Manag. Rev. 2008, 10, 53-73.

62. Freeman, E.R. Strategic Management: A Stakeholder Approach; Pitman: Boston, MA, USA, 1984.

63. Social Accountability International (SAI). Abridged Guidance-2008 Standard, February 2011. Available online: http://www.sa-intl.org/index.cfm?fuseaction=Page.ViewPage\&PageID=1095 (accessed on 26 September 2014).

64. Benoît, C.; Norris, G.; Valdivia, S.; Ciroth, A.; Moberg, Å.; Bos, U.; Prakash, S.; Ugaya, C.; Beck, T. The guidelines for social life cycle assessment of products: Just in time! Int. J. Life Cycle Assess. 2010, 15, 156-163.

65. Draper, S. Creating the Big Shift: System Innovation for Sustainability; Forum for the Future: London, UK, 2013; pp. 2-48.

66. Vermeulen, S.J.; Campbell, B.M.; Ingram, J.S.I. Climate change and food systems. Annu. Rev. Environ. Resour. 2012, 37, 195-222.

67. Schmidt Rivera, X.C.; Espinoza Orias, N.; Azapagic, A. Life cycle environmental impacts of convenience food: Comparison of ready and home-made meals. J. Clean. Prod. 2014, 73, 294-309.

68. Food and Agriculture Organization (FAO). The State of Food and Agriculture. Executive Summary; FAO: Rome, Italy, 2013.

69. Tukker, A.; Huppes, G.; Guinée, J.; Heijungs, R.; de Koning, A.; van Oers, L.; Suh, S.; Geerken, T.; van Holderbeke, M.; Jansen, B.; et al. Analysis of the Life Cycle Environmental Impacts Related to the Final Consumption of the EU-25; Main Report; Institute for Prospective Technological Studies: Sevilla, Spain, 2006.

70. Arcese, G.; Flammini, S.; Martucci, O. Dall'Innovazione Alla Startup-L'esperienza D’imprenditori Italiani in Italia e in California; McGraw-Hill: Milan, Italy, 2013.

71. Teece, D.J. Profiting from technological innovation: Implications for integration, collaboration, licensing and public policy. Res. Policy 1986, 15, 285-305.

72. Von Hippel, E. Comment on "Is open innovation a field of study or a communication barrier to theory development?” Technovation 2010, 30, doi:10.1016/j.technovation.2010.09.004.

73. Cassiman, B.; Veugelers, R. In search of comple-mentarity in innovation strategy: Internal R\&D and external knowledge acquisition. Manag. Sci. 2006, 52, 68-82.

74. Beamish, P.W.; Lupton, N.C. Managing joint ventures. Acad. Manag. Perspect. 2009, 23, 75-94.

75. Grindley, P.C.; Teece, D.J. Managing intellectual capital: Licensing and cross-licensing in semiconductors and electronics. Calif. Manag. Rev. 1997, 39, doi:10.2307/41165885. 
76. Gassmann, O. Opening up the innovation process: Towards an agenda. $R \& D$ Manag. 2006, 36, 223-228.

77. Lichtenthaler, U. Open innovation: Past research, current debates, and future directions. Acad. Manag. Perspect. 2011, 25, 75-93.

78. Arcese, G.; Flammini, S.; Lucchetti, M.C.; Martucci, O. The evolution of open innovation in large firms. In Proceedings of the 19th IGWT Symposium on Commodity Science in Research and Practice-Current achievements and Future Challenges, Cracow, Poland, 15-19 September 2014.

79. Gassmann, O.; Enkel, E. Constituents of open innovation: Three core process archetypes. $R \& D$ Manag. 2006, in press.

80. Gellynck, X.; Vermeire, B.; Viaene, J. Innovation in food firms: Contribution of regional networks within the international business context. Entrep. Reg. Dev. 2007, 19, 209-226.

81. Omta, O.S. Innovation in chains and networks. J. Chain Netw. Sci. 2002, 2, 73-80.

82. Kühne, B.; Lefebvre, V.; Gellynck, X. Knowledge exchange in innovation networks: How networks support open innovation in food SMEs. Proc. Food Syst. Dyn. 2013, 73, 181-196.

83. Lazzarotti, V.; Manzini, R. Open innovation in the food and drink industry. Available online: http://webcache.googleusercontent.com/search?q=cache:VNwDNum1cPEJ:www.va.camcom.it/files/ innovaz/I20_InterventoLIUC_OpenInnAgrofood.pptx+\&cd=1\&hl=it\&ct=clnk\&gl=it (accessed on 1 October 2014).

84. Vanhaverbeke, W.P.M.; de Rochemont, M.H.; Meijer, E.; Roijakkers, A.H.W.M. Open Innovation in the Agri-Food Sector; TransForum: Cologne, Germany, 2007.

85. Costa, A.I.; Jongen, W.M.F. New insights into consumer-led food product development. Trends Food Sci. Technol. 2006, 17, 457-465.

86. Chesbrough, H.; Crowther, A.K. Beyond high tech: Early adopters of open innovation in other industries. R\&D Manag. 2006, 36, 229-236.

87. Bigliardi, B.; Galati, F. Innovation Trends in the food industry: The case of functional foods. Trends Food Sci. Technol. 2013, 31, 118-129.

88. Avermaete, T.; Viaene, J. On innovation and meeting regulation: The case of the Belgian food industry. In Proceedings of the DRUID Summer Conference on Industrial Dynamics of the New and Old Economy: Who is Embracing Whom? Copenhagen, Denmark, 6-8 June 2002.

89. Acosta, M.; Coronado, D.; Ferrándiz, E. Trends in the acquisition of external knowledge for innovation in the food industry. In Open Innovation in the Food and Beverage Industry; Martinez, M.G., Ed.; Elsevier: Cambridge, UK, 2013; pp. 3-24.

90. Kemp, S.E. Consumers as part of food and beverage industry innovation. In Open Innovation in the Food and Beverage Industry; Martinez, M.G., Ed.; Elsevier: Cambridge, UK, 2013; pp. 109-138.

91. Baregheh, A.; Rowley, J.; Sambrook, S. Towards a multidisciplinary definition of innovation. Manag. Decis. 2009, 47, 1323-1339.

92. Yin, R.K. Case Study Research: Design and Methods; Sage Publications: Thousand Oaks, CA, USA, 2013.

93. Eisenhardt, K.M.; Graebner, M.E. Theory building from case studies: Opportunities and challenges. Acad. Manag. J. 2007, 50, 25-32.

94. Stake, R. Multiple Case Study Analysis; Guilford Press: New York, NY, USA, 2006; p. 342. 
95. Abrahamson, S.; Ryder, P.; Unterberg, B. Crowdstorm: The Future of Innovation, Ideas, and Problem Solving; John Wiley \& Sons: Hoboken, NJ, USA, 2013; pp. 11-13.

96. Rodriguez, M.A.; Ricart, J.E.; Sanchez, P. Sustainable development and the sustainability of competitive advantage: A dynamic and sustainable view of the firm. Creat. Innov. Manag. 2002, 11, 135-146.

97. Betacup Project. Available online: https://betacup.jovoto.com/ideas/4751 (accessed on 30 September 2014).

98. Back to the Roots. Available online: https:/www.backtotheroots.com/ (accessed on 30 September 2014).

99. Elks, J. Back to the Roots Growing Food Education, Reducing Waste Thanks to Smart Design. Available online: http://www.sustainablebrands.com/news_and_views/waste_not/back-rootsgrowing-food-education-reducing-waste-thanks-smart-design (accessed on 30 September 2014).

100. Kickstarter Inc. Available online: https://www.kickstarter.com/?ref=nav (accessed on 22 June 2015).

101. Arora, N.; Velez, A. Home Aquaponics Kit: Self-Cleaning Fish Tank That Grows Food; Kickstarter Inc.: New York, NY, USA, 2012.

102. The Plant. Available online: http://www.plantchicago.com/ (accessed on 30 September 2014).

103. Venie, E. The Plant. Iitmagazine 2012. Available online: http://www.iit.edu/magazine/winter_ 2012/article_1.shtml\#top (accessed on 30 September 2014).

104. Scott-Thomas, C. Unilever Outline New Open Innovation “Challenges and Wants". Available online: http://www.foodnavigator.com/Business/Unilever-outlines-new-open-innovationchallenges-and-wants (accessed on 29 May 2015).

105. Unilever. 2015. Available online: http://www.unilever.com/about/innovation/open-innovation/ (accessed on 29 May 2015).

106. Nestlé in Society. Available online: http://www.nestle.com/asset-library/documents/library/ documents/corporate_social_responsibility/nestle-csv-full-report-2012-en.pdf (accessed on 29 May 2015).

107. Coca-Cola Sustainability Report 2013. Available online: http://assets.coca-colacompany.com/ 44/d4/e4eb8b6f4682804bdf6ba2ca89b8/2012-2013-gri-report.pdf (accessed on 29 May 2015).

108. Thota, H. Kraft and Unilever pathways to innovative leadership. Innov. Beverage Innov. 2012, 10, 26-29.

109. NineSights. Available online: https://ninesights.ninesigma.com/web/kraft-gallery (accessed on 30 May 2015).

110. Molinos Rio de la Plata. Available online: https://ninesights.ninesigma.com/web/kraft-gallery (accessed on 30 May 2015).

111. Zero Carbon Food. 2015. Available online: http://www.zerocarbonfood.co.uk (accessed on 30 May 2015).

112. Rayapura, A. Startup Growing “Zero Carbon Food” in London Underground Tunnels Has Investors Clamoring Sustainable Brands the Bridge to Better Brands, 2014. Available online: http://www.sustainablebrands.com/news_and_views/startups/aarthi_rayapura/startup_growing_z ero_carbon_food_london_underground_tunnels_(accessed on 29 May 2015).

113. Tate \& Lyle. 2014. Available online: http://www.tateandlyleopeninnovation.com/Pages/Home.aspx (accessed on 30 May 2015). 
114. Chesbrough, H. Open Business Models: How to Thrive in the New Innovation Landscape; Harvard Business Press: Boston, MA, USA, 2013; p. xii.

115. European Commission. EU Food Market Overview. Available online: http://ec.europa.eu/ enterprise/sectors/food/eu-market/index_en.htm (accessed on 30 September 2014).

116. Wielens, R. Accelerating the innovation cycle through intermediation: The case of Kraft's melt-proof chocolate bars. In Open Innovation in the Food and Beverage Industry; Martinez, M.G., Ed.; Elsevier: Cambridge, UK, 2013; pp. 62-73.

(C) 2015 by the authors; licensee MDPI, Basel, Switzerland. This article is an open access article distributed under the terms and conditions of the Creative Commons Attribution license (http://creativecommons.org/licenses/by/4.0/). 